ORIENTE
ORIENTE MODERNO $98(2018) 52-72$
MODERNO
brill.com/ormo

\title{
Giovanni Battista Raimondi's Travel in the Middle East
}

\section{A Case of Sixteenth-Century Portuguese-Italian Interference}

\author{
Margherita Farina \\ Kunsthistorisches Institut in Florenz \\ ritafarina@gmail.com
}

\begin{abstract}
The paper publishes the inedited document Miscellanea Medicea 719, ins. 56, n. 1 of Florence State Archive, containing the account of a journey by land from Hormuz to Venice, dated to 1575 , preceded by a brief critical introduction. 19th century Italian historiography has attributed the account to Giovanni Battista Raimondi (1536 ca.-1614), scientific director of the Typographia Medicea (Rome 1584). Raimondi has been considered also as the author of the travel, describing his experience in the first person (plural). This paper argues, on linguistic and text-critical grounds, that Raimondi did not make such a travel, nor did he compose the account, but merely copied the document in the context of the preparation of a mission to Egypt and Persia of Giovanni Battista Vecchietti, who left to Alexandria in 1584 , as a papal envoy.
\end{abstract}

\section{Keywords}

G. B. Raimondi - Typographia Medicea - Hormuz - Safavid Persia - Portuguese-Italian linguistic interference

* This work was produced within the Deutsche Forschungsgemeinschaft Project "Die Typographia Medicea im Kontext: Text und Bild als Medien des Kultur- und Wissenstransfers zwischen europäischen und orientalischen Kulturräumen um 160o", directed by Eckhard Leuschner-Würzburg University and Gerhard Wolf-Kunsthistorisches Institut in Florenz, Max-Planck-Institut. 


\section{$1 \quad$ Introductory Remarks}

The folders 717 to 722 of the Miscellanea Medicea (Misc. Med.) in Florence State Archive contain documents relating to the Typographia Medicea, a printing press established in 1584 by Cardinal Ferdinando de' Medici (later Grand Duke Ferdinando I), under the auspices of Pope Gregory XIII, for the print of Oriental languages. ${ }^{1}$ The scientific director and curator of all the press' activities was Giovanni Battista Raimondi (Naples?, 1536 ca.-Rome, 1614), mathematician and orientalist who managed the Typographia from the foundation until his death. ${ }^{2}$ Raimondi studied the texts, he edited them and prepared manuscript copies that would serve as models for the printed editions. He supervised every phase of the print of all the Typographia's editions. He also coordinated the work of all the people involved and took care of all financial details.

Raimondi's tireless work is witnessed by the dozens of manuscripts copied and annotated by him, by his amazing collection of oriental manuscripts and by a vast and multifarious archival documentation preserved today in various Italian libraries. ${ }^{3}$

The rich narrative that we are able to reconstruct for Raimondi's scholarly activity contrasts with the scanty information that we have on his life. Most of all, we still ignore how, when and where did he manage to learn and master so many languages and writings (Raimondi was also a skilled calligrapher).

Struggling with this embarrassing lacuna, 18th and 19th century archivists and historiographers have attributed to Raimondi a travel account contained in the beginning of section n. $5^{6}$ of Misc. Med. 719 (ff. 1-5). The document is entitled "Viagio per terra de hindia orientale à Venetia"4 and the person who ranged the file some time in the 19th century added the following annotation: "V'è in principio la relazione d'un viaggio per terra dall'India Orientale a Venezia, fatto da G. B. Raimondi, partendo da Ormus per il Bandel il sabato 26 febbrajo e tornando a Venezia il 3 dicembre 1575 . È tutta di suo pugno". ${ }^{5}$ Along

1 On this enterprise see, among others, Saltini (1860), Tinto (1987) Levi Della Vida (1939), Tinto (1987), Piemontese (1989), Jones (1994), Fani and Farina (2012).

2 On Raimondi and his work for the Typographia Medicea see Saltini (1860), Piemontese (1993), Jones (1981), Farina (2012) and Fani (2012), among others.

3 The Biblioteca Medicea Laurenziana, the Archivio di Stato and the Biblioteca Nazionale in Florence, the Biblioteca Apostolica Vaticana and the Biblioteca Marciana in Venice.

4 "Travel overland from East India to Venice."

5 "At the beginning [sc. of the section] is the account of a travel overland from East India to Venice, made by G.B. Raimondi, leaving from Ormuz to Bandel on Saturday 26 of February, getting back to Venice on December the 3 rd of 1575 . It is entirely in his own handwriting". 
the same lines is the reconstruction by Saltini, ${ }^{6}$ who nevertheless stresses the lack of any detailed information on the circumstances of such a travel. In fact, we have no other hint throughout the entire documentation on Raimondi's life and activities regarding his visit to any Eastern country.

This paper presents a transcription of Misc. Med. 719, doc. 56, ff. 1-5, with some introductory remarks and a brief commentary.

The account, as well as the travel described in it, are thus ascribed to Raimondi exclusively on the basis of the handwriting, which is clearly his own, as can be easily verified by comparing this document to the hundreds of other documents by his hand in the Misc. Med. The text is copied on a paper displaying a watermark frequently found in Raimondi's materials and in documents relating to the Typographia: a dove standing on a trimontium, within a circle. $^{7}$

However, as I will argue in what follows, several considerations compel us to reject such an attribution and to consider this document simply as a copy that Raimondi made of a travel account, for the use of the press' activities. Raimondi's authorship was already questioned by Piemontese, ${ }^{8}$ who first pointed out a chronological incongruence: the dating of the document, 1575 , is hardly compatible with Raimondi's biography, as we know that between 1574 and 1576 he was teaching mathematics at the university La Sapienza in Rome. ${ }^{9}$

A travel to the Middle East and back, in those days, would have taken several months, as witnessed by the Viagio itself, describing an almost ten-month trip.

To this we could add that the account is part of a section of Misc. Med. 719 devoted to the preparation of a travel of the merchants Giovanni Battista Britti and Giovanni Battista Vecchietti to Egypt, Ethiopia and Persia, on behalf of Pope Gregory XIII and Ferdinando de' Medici. ${ }^{10}$ On this occasion Raimondi collected and copied from different sources a great amount of information on the itinerary to be followed, the necessary travel expenses and the main difficulties of the trip. ${ }^{11}$ From a document at the ff. 35-36 we know that Raimondi commissioned detailed reports to informers that we are not able to identify.

$6 \quad$ Saltini (1860), p. 265 and n. 5 .

7 Briquet (1923 [2000]), n. 12250. The same watermark is found, for example, in Misc. Med. 719, doc. 4 and doc. 38, by Raimondi's hand, and in the manuscript Magliab. Cl. III 102 f. 8, Florence, National Library (inventory of the books and materials of the Typographia Medicea around 1595).

8 Piemontese (2007): 369 .

9 Piemontese (2007): 369 .

10 Almagià (1956), Piemontese (2007), among others. On the content of these instructions see Farina (2012) p. 48-50.

11 Misc. Med. 719, doc. 56, ff. 35-40 and 45-46. 
Had he made such a travel himself just a few years earlier, he would have had possibly more first-hand information and would not have needed to request and collect so many details.

However, besides these first pragmatic difficulties and these speculations, other text-internal arguments can help us not only to exclude Raimondi as an author, but also to reconstruct the document's provenance.

To provide terms of comparison for a number of linguistic phenomena in late 16th century Italian, in Raimondi's socio-linguistic environment, a digital database of archival documents (mostly letters) related to the Medici family from Florence State Archive (ASF) was used in this study: the $\beta$ i $\alpha$ database of the Medici Archive Project. ${ }^{2}$

Analysis of Misc. Med. 719, doc. 56, ff. 1-5

\section{a) Contextual Observations}

First of all, the narrator uses some expressions suggesting that he identifies himself with the Portuguese inhabitants of Hormuz and with some Portuguese representatives in Persia.

In the very beginning of the account (f. rr), talking about the fortress of Bandel, ${ }^{13}$ possibly Bandel de Camoraõ, later Bandar 'Abbās, he refers to the "Capitanio della fortezza che è nostra". ${ }^{14}$ We know that in those days the fortress of Hormuz, as well as the fortresses Larak and Bandar-e-Cong, on the Persian side of the strait, were controlled by the Portuguese.

The Persian city of Lār is designated as $<$ Lara $>$, according to the Portuguese and Spanish version of the toponym, as opposed to the form Lar, which is found in Italian sources, such as in Gastaldi's 1561 map of Asia.

The narrator, on $\mathrm{f} .3 \mathrm{v}$, mentions the term $<$ dodiaz $>$, referring to a kind of carpet produced in Kashan. This word was apparently coined by the Portuguese merchants in Persia, as a corrupted form of the name of the city of Yazd, where very precious carpets were produced (see infra).

Finally, in <Casbin, $>$ to be probably identified with Qazvinn, the traveller encountered "un nostro Ambasciadore il quale non usciva fuori di casa, et haveva 20 portughesi di guardia alli quali pregavano li turchi che si facessero

\footnotetext{
12 http://www.medici.org [10/10/2015]. The author thanks the Medici Archive Project staff for granting access to the database.

13 The term "bandel", a loanword from Persian بَ bandar, meaning "port".

14 "The captain of the fortress, which is ours".
} 
renegati". ${ }^{15}$ Although other options could be possible, it is reasonable to assume that the twenty Portuguese were guarding the Portuguese ambassador's residence.

\section{b) Orthographic Interference}

The orthography of the entire text is wonky and displays some peculiarities that are incompatible with Raimondi's complete mastery of Italian writing and with the general features of all other Italian documents written by him.

The writer seems to struggle with double consonants. While he spells $<$ Marzzo $>$ on ff. $1 \mathrm{v}$ and 2 r, he also repeatedly omits a number of double consonants: <viagio $>$, <hogi $>$ (f. ir et passim), <levasemo $>$, <s'atraversano $>$ (f. ir), $<$ caminamo $>$ (f. 1v), <cità $>$ (f. iv et passim), $<$ camina $>$, $<$ vale $>$, < <abondantissimo $>$, <matina $>$ (f. 2 r), <linguagio $>$, <passagieri $>$ (f. 2v), $<$ cameli $>$ (f. $4 \mathrm{r}$ ), etc. Although many of these spellings can reflect the pronunciation of certain Italian dialects, they do not correspond to any coherent dialectal system. Many of these spellings may, on the other hand, be explained by comparing them to pronunciation and spelling of their Portuguese cognates: viajem, hoje, atravessar, caminhar, vale, abundante, linguagem, passageiros, camelos.

As a term of comparison, a non-literary and semi-official text, written by Raimondi can be considered: Misc. Med. 719 doc. 54, an inventory of the materials of the Vatican press dating to 1612-1614. Here we find a great number of consistent spellings, confirming Raimondi's mastering of standard Italian orthographic rules, as regards double consonants: <messale $>$, <cassetta $>$, $<$ ferro $\rangle$, <piccole $>$, <comporre $>$, <avantaggi $>,{ }^{16}<$ cancello $\rangle$, <cassoni $\rangle$, $<$ colonne $>$ etc.

Besides the case of double consonants, a number of other words in the Viagio display features that do not correspond to any Italian orthographic uses and rules and are, instead, proper of Portuguese spelling:

- <legue>, occurring eleven times;

- the use of the grapheme $\langle\mathrm{x}>$ to render the phoneme $/ \mathrm{J} /$ for example in $<$ Xatamas $>$, the name of Shah Țahmāsp, and $<$ Xeraz $>$, Shiraz.

- the place names $<$ Cabrestáo $>$ (f. ir), corresponding to the Persian locality Kahurestān, in which the Persian sequence /an/ is rendered with the digramma <áo> and <Bisnao > (f. 3r); in analogous manner, but more

15 F. 3v, "our ambassador, who did not leave his house and was guarded by twenty Portuguese, whom the Turks exhorted renounce their faith".

16 Typographical term equivalent to current modern Italian vantaggi. 
evidently, the name of the city of Kashan, rendered once with $<$ Caixan $>$ and once with $<$ Caixào $>$, a few lines after (f. 3 r).

There is also evidence that Raimondi considered these spellings as foreign. In the case of <legue>, the first occurrence of the term on $\mathrm{f}$. $1 \mathrm{r}$ features in the proper Italian spelling <leghe > only once, possibly due to Raimondi's more or less voluntary emendation. In the case of the grapheme $<\mathrm{x}>$, on f. $2 \mathrm{r}$ Raimondi glossed the names $<$ Xeras $>$ | Xaras $>$ with $<$ Geraz $>$ and the name $<$ Xatamas $>$ with $<$ Sciatamas $>$, bringing back the terms to a more familiar spelling and possibly also, in the case of $<$ Geraz $>$ reproducing the current Italian toponym. ${ }^{17}$

\section{c) Linguistic Interference}

Besides the afore mentioned orthographic issues, several cases of linguistic interference can be detected at different levels of language structure.

In the lexicon, the use of the hybrid form <traversa $>$ on $\mathrm{f}$. 1 , instead of the common Italian traversata, meaning "crossing", can be referred to Protuguese travessa or travessia.

In analogous manner, the term <store $>, 18$ current Italian stuoie, occurring twice on $\mathrm{ff} .4 \mathrm{~V}$ and $5 \mathrm{r}$, might reveal an influence from Portuguese esteira. The form store is documented only once in the $\beta^{\prime} \alpha$ database, in a letter from Malaga, written to Francesco I de' Medici, listing goods arriving from Porto. ${ }^{19}$

Particularly interesting is the case of the city of Qom, mentioned on f. $3 \mathrm{v}$. The passage reads "Giovedì andassemo à dormire in un castello che si chiama Quon que saõ che sono diece legue". ${ }^{20}$ The text which Raimondi copied here clearly presented a Portuguese interference "que saõ", followed by the correspondent Italian che sono. It seems that the first redactor or translator of this text into Italian here inserted a bit of text in Portuguese, due to a lapsus, or, more properly, to code-switching, and then corrected the text into Italian

17 In analogous manner, the Florentine Filippo Sassetti (agent of the Medici family in Cochin) in two letters from 1586 refers to xarafaggio and xaraffo (from Arabic șarräf "cashier, money-exchanger" صرّاف), with reference to the commission charged to Portuguese trade in Goa (Sassetti (1995), p. 495). Sassetti observes: servendo la x alla spagnuola per $s$ (" $x$ being used as $s$ according to the Spanish use," Sassetti (1995), p. 512).

18 A kind of rush mat.

19 ASF, Mediceo del Principato 521a, f. 809, the letter was sent by Galeotto dal Borgo on 24 May 1566. The reading <Porto $>$ is reconstructed by the editors. The word stuoie is attested in four Italian documents from the same database, once in a letter from Tommaso di Iacopo de' Medici to Tommaso Salviati, dated 1566 mentioning some "stuoie di cannuccie" (ASF, Mediceo del Principato 221, f. 13).

20 "On Thursday we went to sleep by a castle named Quon que saõ, which is ten leagues far". 
"che sono". Raimondi, apparently, when copying the text, did not realize what had happened and reproduced the mistake in his copy (or maybe even misinterpreted "Quonquesaõ" as a toponym, due to the influence of writings like $<$ Cabrestaò $>$ ?).

As regards morphology, an influx from Portuguese could be detected in the plural forms < mocaris $>$ (f. $1 \mathrm{r}$ ) and <larins $>$ (ff. $2 \mathrm{v}$ and $4 \mathrm{r}$ ). The singular form of the term in Persian is mokāri , "muleteer, cameleer" and the plural of nouns in Persian is expressed through the endings $-\bar{a} n$ or $-h \bar{a}$. Hence the form <mocaris> is not literally transposed from its language of origin, but is rather adapted to the morphology of the target language. In Italian pluralisation is never achieved by means of final $-s$, but it is in Portuguese: conde "count", condes "counts". The same can be observed for <larins>, from Persian lāri, called larin in the European sources (v. infra), a coin named after the city of Lār.

A prominent morpho-syntactic feature of the Viagio is the pervasive and consistent use of forms of the imperfect subjunctive in independent clauses, instead of the imperfect and indicative: as an example, on ff. $\mathrm{rr}-\mathrm{v},<$ partissimo $>$, $\langle$ stessimo $\rangle,\langle$ domandassimo $\rangle$, <caminassemo $\rangle$, <andassemo $\rangle,\langle$ partesimo $\rangle$, $<$ levassemo $>$ etc. This irregular and unfamiliar use of the imperfect subjunctive cannot be referred to any peculiar use of 16 th century Italian. It should be remarked that many of these subjunctives diverge from standard Italian and reveal a clear Portuguese interference: andássemos, caminhássemos, levássemos etc. At the same time, the few documented forms of preterite display the above mentioned orthographic tendency to omit double consonants: <dormimo> (f. Ir), <partimo > f. 2v, comparable to Portuguese dormimos, partimos.

At the syntactical level, the expression "aspettando per cafila" (ff. iv and $3 r$ ), that could be considered as a calque from Portuguese esperar por ${ }^{21}$ as the Italian verb "aspettare", unlike its Iberian cognates, is not commonly constructed with the preposition "per". 22

Inconclusive, instead, is the presence of the expression "fu morta" in "la figliola di Mahomed che dicono che fù morta in guerra dalli Christiani"23 (f. 3v). Here the verb morire "to die" is clearly used transitively, in a passive structure with the explicit agent "dalli Christiani". Even though, according the current syntax of modern Italian, morire is intransitive, the use of this verb in

\footnotetext{
21 "To wait for."

22 Not a single occurrence of this syntactical structure with this meaning was elicitated from the $\beta$ i $\alpha$ database.

23 "Muhammad's daughter, whom they say was killed in battle by Christians".
} 
the passive construction is documented for 16 th cent. literary Italian. ${ }^{24}$ Hence it is not compelling to postulate an influence from Portuguese "foi morta" for the above-mentioned passage.

\section{3}

\section{Final Remarks}

On the basis of all these considerations, we can conclude that the Viagio cannot be attributed to Giovanni Battista Raimondi, but could have rather been written by a Portuguese speaker, with a fairly good mastery of the Italian language. It is reasonable to conjecture that Raimondi copied the account when collecting information for the travel of Britti and Vecchietti, around 1584-85. In the beginning, while copying the text, Raimondi more or less consciously adjusted it to Italian orthographic rules, as it is the case, for example, for the first two occurrences of <leghe> (f. rr). However, he soon abandoned these corrections, as long as the text was understandable to him. Raimondi inserted also glosses to personal names and toponyms that, in their original shape, were unfamiliar to him and to his eventual readers (such an operation would not make much sense had he been the actual author of the Viagio).

The reason why Raimondi left unchanged most of the incorrect Italian spellings remains unclear. One could argue that, although not proper, such spellings did not affect the recognition and understanding of the words. Out of his philological spirit and habits, as well as out of a training as a copyist that he presumably had, just like any other literate of his time, Raimondi could have restrained from emending a text when not strictly necessary (the case of $<$ leghe $>$ in this view should be regarded as a lapsus).

One of the most striking oddities of Raimondi's copy of the text is the term <comonsara>, which can be read clearly four times throughout the account. The context indicates that the word is a rendering of the Persian term kārwānsarāy (cf. infra n. 7o). The term was already well-known in Italy the first half of the 16th century ${ }^{25}$ and Raimondi himself, on f. 2r, glosses the Arabic loanword $<$ cafila $>$ with $<$ caravana $>$. It is unclear, therefore, how the misreading

\footnotetext{
24 E.g. "che tutto credesi lo facia per colera che tuttavia tiene di quello pavese che fu morto da scolari nel tempo che lui era ultimamente in Pavia" (Aviso from Milan, 1579, ASF, Mediceo del Principato 3254, f. 472); "fu preso quello timoroso homicida di quello che con una accetta fu morto alla Piazza di Pasquino" (Aviso, Rome, 1580, ASF, Mediceo del Principato 4027 , f. 183).

25 The term is attested in the forms carvasarà, carvassarà, carvasaràn, carvasara in Michele Membré's travelogue (cf. Membré (1542), p. 200).
} 
$<$ comonsara > originated and why it was not corrected, misleading as it is for someone looking for practical information for organizing an expedition.

Besides Raimondi's skills and intention as a copyist, other aspects of the Viagio's composition and use should be considered. As a report, the text aimed at being understood by an Italian public, probably the Papal chancery (see infra). Raimondi's intent in copying the text was gathering and transmitting information on the routes to Persia and India and back, for the mission of Britti and Vecchietti. Hence, we must assume that the text, in spite of its orthographic oddities and linguistic inconsistencies was comprehensible enough for its readers, who did not consider it necessary to correct it and uniform it to the standard they were used to. ${ }^{26}$

On the identity of the original author of the Viagio one can but speculate. As was already noticed, he had good mastery of the Italian language. The presence of Portuguese graphemes $<\mathrm{x}>$ and $<$ aó $>$, and most of all the code-switching in "Quon que saõ" suggest that the text was originally written in Italian by the Portuguese author (either as a self-translation or as direct composition), rather than secondarily translated by someone else. The familiarity of the author with Italian, the Roman context in which we can assume that Raimondi had access to the text, together with some remarks, such the notice, on $\mathrm{f}$. $2 \mathrm{v}$, that three larins are equivalent to "sei giulij" (a Papal coin), suggest that the Viagio was composed by someone related to the Roman curia. This hypothesis was already put forward by Piemontese, who suggested a papal envoy as the author both of the travel and of the Viagio. ${ }^{27}$

Document Transcription

Miscellanea Medicea 719, doc. 56 ff. $1-5^{28}$

Viagio per terra de hindia orientale à Venetia

26 On standards an linguistic interintelligibility in 16th century Mediterranean, see Dursteler (2012).

27 Piemontese (2007), p. 369 "Ma anziché il proprio viaggio, egli ha forse registrato quello di ritorno relativo all'inviato pontificio o uno analogo, per promemoria." On information gathering and transmission in Renaissance Rome, see Burke (2002), esp. p. $255^{-256}$ on papal nuncios.

28 In what follows, identifications will be proposed for most of the place names mentioned in the account. Some of them are quite obvious and easily recognizable, some others are less immediate and in some case it was not possible to associate them to any Persian toponym, neither ancient nor modern. 
Partissimo d'Ormus per il Bandel che è terra ferma, dove stessimo otto giorni aspettando cafila ${ }^{29}$ et non la trovando domandassimo al Capitanio della fortezza che è nostra ${ }^{30}$ sette huomini da piede per accompagnarci in uno passo periculoso li quali ci mandò à dare cioè cinque d'archi et frezze et pugnali et li altri dua d'archibugi con due molattieri quali chiamano Mocaris ${ }^{31}$ et caminassemo nostro viagio hogi sabato 26 de febraro 1575 .

Sono dal Bandel à Ormus quatro leghe di traversa per il mare che s'atraversano in barconi che chiamano (terrade) ${ }^{32}$ che serveno per portar acqua in Ormus.

Sabato al tardo partesimo et andassemo à dormire appresso certe casette che chiamano Benalin che sono quattro leghe, et la Domenica andassemo à pranzo appresso certe cisterne che chiamano Gazin ${ }^{33}$ che sono tre legue, per dove vanno molti ladri continuo per dove andassemo dormimo appresso un fiume salato che sono tre legue.

Lunedì avante giorno ci levassemo et ci apparse il giorno appresso à certe case che chiamano Cabrestáo, ${ }^{34}$ da dove andassemo à dormire à un prato che si chiama gibrau che sono sette legue.

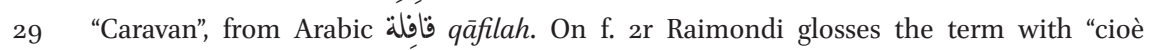
Caravana”.

30 The city and fortress of Hormuz, on the homonymous island. At the time of the Viagio, Hormuz was ruled by the Portuguese, who had conquered the island in 1507 thanks to Alfonso de Albuquerque, and controlled also other harbours and cities on the mainland, such as Bandar 'Abbās, here "Bandel" (see Floor (2004), Floor (2011), p. 87-88: "the kingdom of Hormuz held sway over the Iranian littoral as far as Shilaw, the Persian Gulf islands, in particular Bahrain..."). The first mention of the island in Western sources is by Odorico da Pordenone, who calls it Ormes. For the toponyms of the area, see also the chart in Biedermann (2011), p. 77-78.

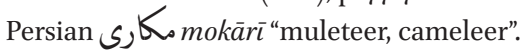

32 Peculiar ships in use in Hormuz were noticed also by the traveller G. B. Britti, who travelled to Ethiopia and India on behalf of Pope Gregory XIII and the Typographia Medicea between 1584 and 1586. In a letter from Goa where he describes his almost two-year travel, he reports: "Da Balsera s'imbarca nelli detti vascelli di Ormuz nella fabrica de quali non vi entra chiodo ne altro ferramento ma en loco loro con corde cuscino le tavole et fanno ogni altra cosa necessaria" (ASF Misc. Med. 719, doc. 8 f. 3v).

33 Probably corresponding to the Guichi mentioned in the Commentaries by de Silva y Figueroa, where the peculiar system if water extraction from the tanks is also described (Figueroa (1903), I, p. 275-276).

34 Kahurestān, mentioned as Kaurestan in a Portuguese document from 1543 (Floor (2011), p. 82) and as Cabrestan in the Commentaries by de Silva y Figueroa (Figueroa (1903), I, p. 277). 
Martedì primo marzzo avante giorno ce levassemo et ci apparse il giorno in un prato che si chiama Guribezargun ${ }^{35}$ da dove andassemo à dormire appresso un pozzo da dove cavano acqua

f. $1 \mathrm{~V}$

per (nantare?) il grano con un bove che chiamano jahon ${ }^{36}$ che sono sette legue.

Mercordi avante giorno ci levassemo et ci apparse il giorno appresso certe cisterne che si chiamano Bettacamacu et passassimo un fiume molte volte che si chiama Tangadalu ${ }^{37}$ et andassemo à dormire à un prato che si chiama Hurmud $^{38}$ che sono otto legue.

Giovedì avante giorno ci levassemo et caminamo tutto il giorno et andassemo à dormire alla cità de Lara, ${ }^{39}$ che sono otto legue sono da Ormus à questa cità quaranta quattro legue le quale andassemo in cinque giorni, dove stessemo quattro giorni aspettando per cafila, qui risiede el Xatamas che ha il Re de tutta la Persia, dico il Re di Lara che è subdito al Re Xatamas questo Re inferiore possede tutto questo contorno de Lara insino al Bandel. ${ }^{40}$

Martedì otto di Marzzo al tardo partessimo di questa cità di Lara ${ }^{41}$ et andassemo à dormire appresso una cisterna che si chiama Bonamira dove pagano per ogni cavalcatura uno besti, ${ }^{42}$ che vale quandici quadrini et andassemo alla cità de Xaras. ${ }^{43}$

Mercordi andassemo à dormire à uno prato che si chiama Gurdi che sono sette legue.

35 Gūr-i-Bāzargān. The toponym is mentioned by Pietro Della Valle as Guri Bzargon (Gaeta and Lockhart (1972)).

36 Cf. Gehun in Figueroa (1903), I, p. 282.

37 Cf. Tango Talan Figueroa (1903), I, p. 282 and ff.

38 The toponym Hormuz, Hormoz, Hormud is widespread in the inland in front of Hormuz island. Here the reference is probably to modern-day Hormoz, on the mountains of Larestān.

39 The city of Lar. "Lara" (also "Laara", or "llara") is the name of the city in many 16 th century Portuguese sources and maps of the Persian Gulf (see, e.g., Biedermann (2011)), p. 78.

40 Shah Țahmāsp I (1514-1576), second shah of the Safavid dynasty, who ruled Iran from 1524 (see Mitchell (2009)).

41 Lār.

42 Bisti is the name of a Safavid silver coin, equivalent to 20 dinars (literally bisti means "twenty"), cf. Matthee; Floor; Clawson (2013), p. 46, 374.

43 The city of Shiraz, here also "Xeras", glossed by Raimondi as "Geraz" (v. infra). 
Giovedì avante giorno ci levassemo et andassemo al fare del giorno ad un prato che si chiama Biri ${ }^{44}$ da dove andassemo a dormire àd uno castello dove vanno sempre ladri, che si chiama Dechu ${ }^{45}$ che sono sette legue.

f. $2 r$

Venerdì andassemo à dormire ad un castello che si chiama Giuon ${ }^{46}$ che sono nove legue, qui stessimo il sabato reposando.

Domenica partessimo et andassemo à dormire in certe case et un pozo che si chiama Chatelega, dove pagano d'ogni cavalcatura uno besti et sono sette legue.

Lunedì andassemo doi parte d'una montagna che si chiama $\mathrm{Andu}^{47}$ la quale se camina girando et nella quale andassimo cinque legue.

Martedì fenimo d'andare il restante et à mezzo giorno arrivassemo ad un castello che si chiama Jaharu ${ }^{48}$ che sono quattro legue, il quale castello è abondantissimo

Mercordi andassemo à dormire appresso una cisterna che si chiama Garucaseta che sono cinque legue pagassemo d'ogni cavalcatura un besti.

Giovedì andassemo à dormire ad un prato appresso un arbori grande che si chiama Gaspir ${ }^{49}$ che sono sette legue.

Venerdì andassemo à dormire appresso un fiume che si chiama Paghera p Pageia che sono otto legue.

Sabbato andassemo à dormire appresso una montagna che si chiama Chumben che sono cinque legue.

Domenica andassemo à dormire appresso certe case che si chiamano Themeun che sono cinque legue.

Lunedì andassemo à dormire appresso uno vale grande appresso la cità de Xeras $_{\text {Geraz }}$ che sono cinque legue.

Martedì che furono 22 di Marzzo la matina arrivassemo à questa cità di Xeras ${ }^{G e r a z}$, la quale non ha muraglie, et ha belli bazari che vogliono dire

44 Cf. Bir in Figueroa (1903), I, p. 304.

45 Possibly Dehkuyeh, or Deh-i-Khir, mentioned as Dechair by Pietro Della Valle Gaeta and Lockhart (1972). Cf. also Diacuri in Figueroa (1903), I, p. 303?

46 Cf. Guin in Figueroa (1903), I, p. 306.

47 Reference to a very steep and winding mountain route on the way to Jahrom is also found in Figueroa (1903), I, p. 309-310.

48 Possibly Jahrom. Cf. Jarun in Figueroa (1903), I, p. 309.

49 Figueroa (1903), I, p 352, in the vicinity of Shiraz, describes a great cypress tree: un çipres antichissimo, de tan grueso pie que quatro honbres apenas podían rrodeallo estendidos los braços ("a very ancient cypress tree, with a trunk so large that four men could barely encircle it by stretching their arms"). 
boteghe de mercanzie qui resiede un figliolo de Xatamas ${ }^{\text {Sciatamas50 }}$ et qui stessimo quaranta giorni aspettando Cafila cioè Caravana sono le case di mattone, et le porte per dove entrano

f. $2 \mathrm{~V}$

alte cinque palmi al più et quando entrano levano le tromolanti ${ }^{\mathrm{i} \text { turbanti }}$ della testa per potere entrare.

Domenica partimo di questa cità di Geraz Xeras per la cità di Saba han ${ }^{51}$ che fù al di primo di Magio et andassemo à dormire un miglio et mezo lontano sopra certe fosse de turchi morti.

Lunedì di poi messa in ordine la Cafila andassemo à dormire appresso un fiumetto che si chiama Salviva che sono due legue et partessimo dopo pranzzo.

Martedì andassemo à dormire appresso certe case che si chiama il luogo Zargun $^{52}$ et sono quattro legue.

Mercordi andassemo à dormire ad un fonte che si chiama Aguara, et pagano per ogni cavalcatura uno besti sono cinque legue.

Giovedì andassemo à dormire appresso un fonte che chiama Main ${ }^{53}$ dove pagano per ogni cavalcatura uno besti, sono cinque legue.

Venerdì andassemo à dormire appresso una torre dove dicono che sta sepolto uno figliolo di Mahmed, et la torre si chiama Imame, ${ }^{54} \mathrm{c}$ he sono cinque legue.

Sabbato andassemo à dormire ad un luogo che si chiama Angurin che sono cinque legue.

Domenica andassemo à dormire appresso un villaggio, che si chiama Aspaes, ${ }^{55}$ dove pagano li passagieri de saugale [sic] che in nostro linguagio vol dire tributo secondo gli domandano noi pagassemo tre larins ${ }^{56}$ per esser forastieri, facendoci in ciò assai favore che sono sei giulij sono quattro legue.

5o Raimondi's transcription can be compared to Filippo Sassetti's rendering of the same name in a letter from Cochin dated 1585: Scià Tamas (Sassetti (1995), p. 463).

$5^{1}$ Most probably Isfahan. Cf. f. $3 \mathrm{r}<$ Sebahain $>$, possibly to designate the same locality.

$5^{2}$ Or, most probably, Zargan, the spelling is unclear. It corresponds to modern Zarqan, $\mathrm{cf}$. also Zargan in Figueroa (1903), I, p. 368.

53 Mahin in Figueroa (1903), I, p. 368.

54 The site could be identified with an Imamzadeh (a Shi'i sanctuary dedicated to the venerable offspring of an Imam), mentioned as Amanzada and Emanzada in Figueroa (1903), II, p. 9;52, where the traveller describes a great mosque and the tomb of un grandeyvenerable sancton ("a great and venerable holy man") where pilgrims are hosted.

55 Aspas. Cf. also Acopaz in Figueroa (1903), II, p. 12.

56 The lari, or larin (Persian läri) in the European sources, is a silver Safavid coin with elongated shape, named after the city of Lār (see Matthee; Floor; Clawson (2013), p. 47, 372). An early description of the lari is found in Membré (1542), p. 61: la moneda della ditta città è uno poco de argento longo doppio con le lettere suso del Re, qual lo chiamano larie tanqua; 
f. $3^{r}$

Lunedì andassemo à dormire ad un castello che si chiama Goscazar ${ }^{57}$ sono cinque legue.

Martedì andassemo à dormire appresso certe case che se chiamano Dargardun $^{58}$ sono sei legue.

Mercordi andassemo à dormire appresso una fortezza che si chiama Set $\operatorname{degaz}^{59}$ che sono otto legue.

Giovedì andassemo à dormire appresso certe case che si chiamano Bisnao Bisnao $^{60}$ che sono otto legue.

Venerdì andassemo à dormire ad un luogo che si chiama Mhair ${ }^{61}$ che sono sette legue

Sabbato, Domenica et Lunedì stessemo reposando in questo luogo.

Martedì andassemo à dormire à Sebahain ch'è una cità che di sopra sono otto legue, dove stessemo quattro giorni aspettando per cafila ha fama della più trista gente di quelle terre, et tale la trovassemo. ${ }^{62}$

e 7 di quelli valeno uno ducato d'oro, siché una moneda de rame ("the coin of that city is a bit of silver, long-shaped and doubled, carrying the letters of the King, which they call lari and tanqua; and 7 of those are worth one golden ducats, that is one copper coin", see also the glossary, p. 211).

57 Kushk-i-zard, mentioned as Cuzcusar in Figueroa (1903), II, p. 13: un buen caravasar y aldea en forma de Fortaleza ... en lengua persiana quiere decir lugar pestilente y venenoso ("a good caravanserai and village in the shape of a fortress... in the Persian language it means pestilential and venomous place").

58 Deh Girdu, mentioned as Dehigirdu by Pietro Della Valle Gaeta and Lockhart (1972), Dergriger in Figueroa (1903), II, p. 13.

59 Yezdikhwāst, mentioned as Izdchast by Pietro Della Valle Gaeta and Lockhart (1972), Hiesdegas in Figueroa (1903), II, p. 13.

6o Busnana, on the map of Persia by Ortelius (1572), p. 166.

61 Mahyar, about $50 \mathrm{~km}$ south of Isfahan. Cf. Mahiar in Figueroa (1903), II, p. 17.

62 Isfahan, Middle Persian Spahan. According to the index of Lockhart; Morozzo Della Rocca; Tiepolo (2006), p. 39o, in the travel accounts on Persia by the Venetians Barbaro and Contarini the toponym features as follows: Saphan, Spaan, Spaham, Spahan, Spama. The city, that was turned into the capital of the Safavid empire by Shah 'Abbās, successor of Shah Țahmāsp, at the time of the Viagio was apparently in decay. The same impression is recorded in Figueroa (1903), II, p. 27-28: Es la ciudad de Spam ... de la grandeza que Xiras, aunque mucho más deformada y arruynada ... siendo cosa feissima y abominable la figura que toda la ciudad tiene ("the city of Spam ... is of the same size as Xiras, although much more disfigured and in riun... being ugly and abominable the appearance of the entire city"). Later on in the description of the city, the account describes new beautiful but still unaccomplished buildings, such as a new mosque, or the king's new caravanserai (p. 30). According to Haneda and Matthee (2006): "Isfahan came under Safavid 
Domenica che furono 22 di Maggio partì di questa cità una Cafila per la cità di Caixan ${ }^{63}$ dove andassemo à dormire ad uno luogo che si chiama Mucha al quale sono diece legue.

Lunedì andassemo à dormire appresso un fiumetto che si chiama Ribate che sono diece legue.

Martedì andassemo à dormire ad una montagna che si chiama Calta ${ }^{64}$ che sono otto legue.

Mercordi andassemo à dormire alla cità di Caixaò ${ }^{65}$ che sono quattro legue. Ha due muraglia di terra, et è circondata d'acqua et passano per ponti per entrare dentro, qui stessemo sette giorni

f. $3 \mathrm{v}$

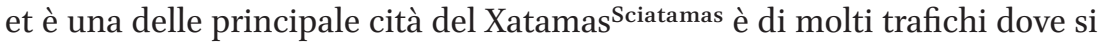
fanno li tappeti che chiamano Dodiaz, ${ }^{66}$ ma li più belli si fanno in Caixan et si portano in Ormus.

Mercordì sequente che furono 2 di Giugno partessimo per Casbind ${ }^{67}$ una Cafila che è dove stà il Re Xatamas sciatamas il quale non si lassa vedere per haver paura che l'ammazzino, et andassemo à dormire in un luogo che si chiama Lebadia che sono otto legue.

Giovedì andassemo à dormire in un castello che si chiama Quon ${ }^{68}$ que saõ che sono diece legue, qui sta sepolta la figliola di Mahomed che dicono che fù morta in guerra dalli Christiani et la Meschita è la più bella cosa che ho visto $\sin$ qui.

rule in 1503 following Shah Esmā'il's defeat of Solțān Morād... No contemporary source describes the conquest of the city in any detail, but we do know that it was accompanied by great brutality.... The Portuguese traveler, Tenreiro, visiting Isfahan in 1524, reports seeing mounds of dirt with bones sticking out that were reportedly the remains of 5,000 people killed by the Safavids."

63 Kashan. Cf. Caxen in Figueroa (1903), II, p. 56.

64 Caltan on the map of Persia by Ortelius (1572), p. 166.

65 Kashan.

66 According to Pedro Teixeira, "dodiaz" is a Portuguese corrupted form of Yazd carpets, namely very precious ones, as the carpets produced in that city of Yazd were considered of extremely high quality (Teixeira and Stevens (1802), p. 243, n. 2). On Safavid carpets and the production in Kashan, see Dhamija (1990) and Walker (1990). Yazd carpets are mentioned, for example, by Marco Polo (Yasdi) and Giosafat Barbaro (Ies/Iesdi, cf. Lockhart and Morozzo Della Rocca (2006), p. 126) in their travel accounts.

67 Qazvīn. Also da Silva y Figueroa will meet Shah Abbās in Qazvīn, in 1617 (cf. Figueroa (1903), II, ch. IV).

68 Qom. 
Venerdì andassemo à dormire in una comonsara ${ }^{69}$ che è una casa scoperta sopra della quale se retirano le cafile et se servono di notte per causa delli ladri et questo sito si chiama (Jorpara) ${ }^{70}$ sono sei legue.

Sabbato andassemo à dormire in un castello che si chiama Saua che sono cinque legue.

Domenica andassemo à dormire in una comonsara che si chiama il setio Dunga $^{71}$ che sono cinque legue. ${ }^{72}$

Lunedì andassemo à dormire in un altro comonsara che si chiama il sitio Heigibi. Sono diece legue.

Martedì andassemo à dormire alla città di Casbin che sono diece legue, qui havemo trovato uno nostro Ambasciadore il quale non usciva fuori di casa, et haveva 20 portughesi di guardia alli quali pregavano li turchi che si facessero renegati, qui stessemo quattro giorni aspettando cafila.

f. $4 \mathrm{r}$

Domenica che furono 18 di Giugno partessimo con una Cafila de cameli per la cità di Taburiz Tauris, et andassemo à dormire ad un prato che si chiama Zigue Zigue, che sono sei legue.

Lunedì andassemo à dormire appresso d'un luogo che si chiama Chalfa sono cinque legue.

Martedì andassemo à dormire in un castello che si chiama Sultania, ${ }^{73}$ che sono sei legue, qui stessemo Mercordi per essere paese fertile.

Giovedì andassemo à dormire in un castello che si chiama Zangu ${ }^{74}$ che sono sei legue.

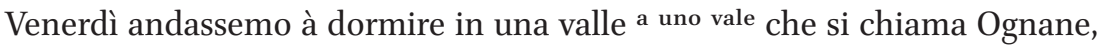
che sono sei legue.

Sabbato andassemo à dormire appresso certe capanne che si chiamano Carconta, sono sei legue.

69 The reading < comonsara > is certain and occurs five times in the Viagio, once even as a toponym (<Comonsara inxa $>$ on f. 4 r). However, it does not seem to make much sense. The term corresponds most probably to something like carvansara, namely "caravanserai" (from Persian kārwānsarāy, cf. also Italian caravanserraglio). In the Commentaries by de Silva y Figueroa (1617) we find the form caravasar (Figueroa (1903), I, p. 274 and passim. Apparently here Raimondi could not decifer correctly what was written in the original text that he was copying.

70 Probably modern Jafarabad, about 6o km from Qom. Cf. Giafarabad in Figueroa (1903), II, p. 74.

71 Dung in Figueroa (1903), II, p. 78.

72 Saveh, about $100 \mathrm{~km}$ rom Qom. Saba in Figueroa (1903), II, p. 76.

73 Sultaniyeh.

74 Zanjan. 
Domenica andassemo à dormire appresso un luogo che si chiama Maijno, sono otto legue.

Lunedì andassemo à dormire appresso certe capanne che si chiamano Comonsara inxa, sono cinque legue.

Martedì andassemo à dormire appresso un luogo, che si chiama Tocomancandi, sono quattro legue.

Mercordi andassemo à pranzo appresso un luogo che si chiama Dhenidar ${ }^{75}$ che sono cinque legue, da dove andassemo à dormire à comonsara che se chiama Dheabes sono tre legue.

Giovedì andassemo à dormire appresso un buono ponte, che si chiama Agebabe sono sei legue.

Venerdì andassemo à dormire alla cita Taburis Tauris, che sono quattro legue, non tiene nessuna muraglia, et è molto grande, et ricca

f. $4 \mathrm{~V}$

qui ci sono di diverse nazioni, li Christiani forastieri et Giudei che non sono del Regno di Persia pagano dieci larins per testa, qui stessemo il giorno di S. Giovanne, et aspettassemo dodeci giorni per Cafila.

Uno lunedì che furono 4 di Luglio partessimo da questa cità per la cità d'Aleppo, andassemo à dormire in certe case che si chiamano Gaustar, sono sei legue.

Martedì andassemo à dormire appresso certe case, dove è un lago d'acqua salata che dicono essere longo di 15 giorni di viagio. Qui si spartisce il regno di Persia da quello del Gran Turco, che è Arabia di Turchia, chiamase questo lago Tasu, ${ }^{76}$ sono sei legue.

Mercordi andassemo à dormire appresso un luogo che si chiama Haruana, sono sei legue.

Giovedì andassemo à pranzo ad un castello che si chiama Sulmasta, ${ }^{77}$ che è l'ultima parte del Regno di Persia. Andassemo a dormire appresso un fiume che si chiama Cantal che sono sei legue, qui cavando carta per scrivere, me dissero che non lo facesse, per che queste terre erano del Turco, et sospettavano male, ne manco lo facesse nell'altre sue.

Di venerdì sino à Mercordi seguente andassemo per una montagna intorno un fiume tanto travagliosa à camminare, che in alcuni luoghi ci erano ponti per potere camminare, per che altramente non se poteva caminare per detto luogo, era come à caminare per le scale al in su et in giù, ci erano in questo fiume alcuni ponti di legno sopra delli quali store di bacchette per passar la

$\begin{array}{ll}75 & \text { Dinidar Ortelius. } \\ 76 & \text { Probably Tasuj, close to the northern shore of Urmiah lake. } \\ 77 & \text { Salmas. }\end{array}$ 
gente, che vederli passare era cosa da ridere per che tremavano di paura, le cavalcature passavano con molto travaglio, alle quali usano mettere dua ordini di cigne et groppiere accio che non caschi la soma.

f. $5 \mathrm{r}$

Giovedì arrivassemo in un castello che si chiama Media ${ }^{78}$ stà in un alto qui stessemo otto giorni et il venerdì sequente andassemo ad un altro che si chiama Dahonquo, ${ }^{79}$ dove stessimo insino alla Domenica qui viveno Armeni, Giudei, et Turchi, et ancora in Media.

Lunedì andassemo à dormire in un luogo che si chiama Paxauon ${ }^{80}$ dove stessimo sino al Giovedì, questo luogo sta sotto il governo dell'Armeni, et paga tributo al Turco, ha questo luogo un fiume che è largo tre tiri di pietra non ha ponte, passano le cavalcature à noto, et le persone et robbe in certi ingegni d'otri gonfi con certi store di bacchette di sopra, deveno essere di trenta otri in circa, quali chiamano palequa et li guidava un huomo. ${ }^{81}$

Venerdì andassemo in una cità che si chiama Nasebin ${ }^{82}$ dove si paga dogana delle robbe et si cerca ogni cosa eccetto le persone, qui stessemo li cinque giorni, et ci dessemo à conoscere à certi Armeni che habitano qui, li quali ci invitorno et mostrorno il sepolcro di Mar Jacob.

Giovedì che furono quattro d'Agosto partessimo er caminassemo venerdì, sabbato, Domenica, Lunedì et Martedì, et il Mercordì arrivassemo in una cità che si chiama Horfa, ${ }^{83}$ che dicono essere il primo paese, che Dio dette ad Abrahàm, qui si paga dogana et al mio compagno chiamorno Mulla che vol dire prete.

\footnotetext{
78 Syriac Amed or Amīd.

79 Duhok.

80 Possibly Faish Khabur.

81 This kind of raft is very common throughout the upper Mesopotamian and Iranian area. River-crossing with inflated goat-skins is described also by Della Valle for the Euphrates: "e tutti, così uomini come donne, passavano il fiume a nuoto con l'aiuto di un otre gonfio di vento che si tengono sotto la pancia ...", Lettera XVII da Baghdàd de' 10 e 23 de decembre 1616 in Della Valle (1843), I, p. 358-359. Representations witnessing a continuity of this practice (with or without rafts) can be found in the Neo-Assyrian relief from North-West palace of Nimrud (British Museum, see Budge (1914), tab. 13), as well as in 15th-16th century Persian and Moghul miniatures (e.g. in the Moscow exemplar of the Book of Babur, probably end of 16th cent., cf. Tyulayev (1960), t. 33, or ms. London, BL, Or. 3714, f. 333vI thank Pier Giorgio Borbone for this reference). Goat-skin rafts are still in use today: see, for example, the interesting comparison in Michaud and Michaud (1980), nn. 31-32).

82 Syriac Nașībīn, modern-day Nusaybin.

83 Urfa (ancient Edessa).
} 
Giovedì andassemo à pranzo al posso di Giacob, che dicono che si aprisse per dare da bere alle pecore, qui li cava l'acqua con uno ingegno di corame.

Venerdì andassemo in una cità che si chiama Alberi, che è molto forte, qui vi è un fiume molto largo d'acqua dolce, dove s'imbarcano li mercanti, che vengono d'Alepo, per Hormuz pigliando porti

f. $5 \mathrm{~V}$

cioè Bagodad Bagdad, Balsora Bassora, qui pigliano nave per andare in Ormuz

Sabbato, Domenica, Lunedì caminassemo alla cità d'Aleppo, che è una molto ricca cità, qui contano intorno docento venetiani mercanti, et uno per nome Sertorio Altano ${ }^{84}$ ci menò à casa sua dove stessemo vinti giorni ammalati.

Mercordi la vigilia della Madonna di settembre, partessimo di Aleppo per Tripoli di Soria, et camminando tre giorni arrivassemo alla città de Mahin, qui stessemo dua giorni, da dove si parte per Hierusalem, che sono tre giorni di viagio, et si trova sempre Cafila

Mercordi arrivassemo à Tripoli di Soria dove stessimo dodici o quattordici giorni aspettando nave

Partessimo di Tripoli per Venetia, et pigliassemo Corfù, dove stessimo tre giorni, et arrivassemo à Venetia in sessantatre giorni, che fu à 3 di dicembre del detto anno 1575 .

\section{References}

Almagià, Roberto. "Giovan Battista e Gerolamo Vecchietti viaggiatori in Oriente". Atti della Accademia Nazionale dei Lincei. Rendiconti di Scienze morali, storiche e filologiche. S. VIII, 9 (1956), p. 313-350.

Biedermann, Zoltán. "Mapping the Backyard of an Empire: Portuguese Cartographies of the Persian Littoral during the Safavid Period". In: R. Matthee; J. Flores (eds), Portugal, the Persian Gulf and Safavid Persia. Louvain, Peeters, 2011, p. 51-78.

Briquet, Charles-Moïse. Les filigranes: dictionnaire historique des marques du papier dès leur apparition vers 1282 jisqu'en 1600 , Leipzig [fac simile Eastford, Ст], Hiersemann [Martino], 1923 [2000].

Budge, E.A. Wallis. Assyrian sculptures in the British Museum. Reign of Ashur-nasir-pal, London, Trustees of the British Museum, 1914.

84 Sertorio Altan, was a wealthy Venetian merchant who resided in Aleppo. Together with his brother Troilo he also handled the postal service between Venice and Hormuz, through a network of Venetian traders connecting Cyprus, Aleppo, Baghdad, Hormuz and India (cf. Pedani (2010), p. 167). 
Burke, Peter. "Rome as a Center of Information and Communication for the Catholic World, 1550-1650". In: Pamela M. Jones; Thomas Worcester (eds), From Rome to Eternity. Catholicism and the Arts in Italy, ca 1550-1650, Leiden, Brill, 2002, p. 253-269. s.v. "Carpets ii. Raw materials ad dyes" (Dhamija, Jasleen), Encyclopcedia Iranica IV, 7, 1990, p. 839-843.

s.v. "Cartpets ix. Safavid Period" (Walker, Daniel), Encyclopcedia Iranica IV, 7, 1990, p. $866-875$.

Della Valle, Pietro. Viaggi di Pietro Della Valle il Pellegrino, descritti da lui medesimo in lettere familiari all'erudito amico suo Mario Schipano, divisi in tre parti, cioè: la Turchia, la Persia e l'India, colla vita e ritratto dell'autore, Brighton, Gancia, 1843.

De Silva Y Figueroa, García. Comentarios de la embajada que de parte del Rey de España don Felipe III hizo al Rey Xa Abas de Persia, Madrid, Sociedad de Bibliófilos Españoles, 1903 .

Fani, Sara. "Gli esiti della Tipografia Medicea”. In: Sara Fani; Margherita Farina (eds). Le vie delle lettere. La Tipografia Medicea tra Roma e l'Oriente, Firenze, Mandragora, 2012, p. 73-84.

Fani, Sara; Farina Margherita (eds). Le vie delle lettere. La Tipografia Medicea tra Roma e l'Oriente, Firenze, Mandragora, 2012.

Farina, Margherita. "La nascita della Tipografia Medicea: personaggi e idee”. In: Sara Fani; Margherita Farina (eds). Le vie delle lettere. La Tipografia Medicea tra Roma e l'Oriente, Firenze, Mandragora, 2012, p. 43-72.

s.v. "Figueroa, García De Silva y" (Bernardini, Michele), Encyclopcedia Iranica, IX, 6 also available online at http://www.iranicaonline.org/articles/figueroa, 1999, p. 612-613.

Floor, Willem. "Two Revenue Lists from Hormuz $(1515,1543)$ ). In: Rudi Matthee; Jorge Flores (eds), Portugal, the Persian Gulf and Safavid Persia, Louvain, Peeters, 2011, p. 81-97.

Gaeta, Franco; Lockhart, Laurence (eds). I viaggi di Pietro Della Valle. Lettere dalla Persia I e II, Roma, Istituto Poligrafico dello Stato, 1972.

s.v. "Hormuz ii. Islamic Period" (Floor, Willem), Encyclopcedia Iranica XII. 5, Winona Lake, Indiana, 2004, p. 471-476.

s.v. "Isfahan vii. Safavid Period" (Haneda, Masashi; Matthee, Rudi), Encyclopcedia Iranica XIII, 6, also available online at http://www.iranicaonline.org/articles/isfahan-viisafavid-period (updated 2012, accessed October 2015), 2006, p. 650-657.

Jones, Robert. The Arabic and Persian Studies of Giovan Battista Raimondi (c. 15361614). PhD dissertation. University of London (Warburg Insitute), 1981.

Jones, Robert. "The Medici Oriental Press (Rome 1584-1614) and the Impact of its Arabic Publications on Northern Europe”. In: A. Russel Gül (ed.), The 'Arabick' Interest of the Natural Philosophers in Seventeenth-Century England, Leiden, Brill, 1994, p. 88-108. 
Levi della Vida, Giorgio. Ricerche sulla formazione del più antico fondo dei manoscritti orientali della Biblioteca Vaticana, Città del Vaticano, Biblioteca Apostolica Vaticana. Studi e Testi, 1939 .

Lockhart, Laurence; Morozzo della Rocca, Raimondo; Tiepolo, Maria Francesca. I viaggi in Persia degli ambasciatori veneti Barbaro e Contarini, Roma, Istituto Poligrafico dello Stato, 2006.

Matthee, Rudi; Floor, Willem; Clawson, Patrick. The Monetary History of Iran: From the Safavids to the Qajars, London, I.B. Tauris, 2013.

Membré, Michele. Relazione di Persia (1542), Napoli, 1969.

Michaud, Roland; Michaud, Sabrina. Mirror of the Orient, Boston, 1980.

Ortelius, Abraham. Theatrum Orbis Terrarum. Gedruckt zu Nuermberg durch Johann Koler Anno MDLXXII, Repr. Darmstadt, 2006 Ute Schneider (ed.), 1572.

Pedani, Maria Pia. Venezia Porta d'Oriente, Bologna, il Mulino, 2010.

Piemontese, Angelo Michele. Catalogo dei manoscritti persiani conservati nelle biblioteche d'Italia, Roma, Istituto Poligrafico dello Stato, 1989.

Piemontese, Angelo Michele. "Leggere e scrivere 'Orientalia' in Italia”. Annali della Scuola Normale Superiore di Pisa. Classe di Lettere e Filosofia. S. 3. 23, II (1993), p. 427-453.

Piemontese, Angelo Michele. "La diplomazia di Gregorio XIII e la lettera del re di Persia a Sisto V". Miscellanea Bibliothecae Apostolicae Vaticanae. 14 (2007), p. 363-409.

Saltini, Guglielmo E. "Della stamperia medicea orientale e di Giovan Battista Raimondi”. Giornale storico degli archivi toscani. 4 (1860), p. 257-308.

Sassetti, Filippo. Lettere dall'India (1583-1588), a c. di Adele Dei, Roma, Salerno, 1995.

Stevens, John. The Travels of Pedro Teixeira: With His "Kings of Harmuz" and Extracts from His "Kings of Persia", London, Haklyut Society, 1802.

s.v. "Ṭahmāsp I" (Mitchell, Colin P.), Encyclopcedia Iranica, online edition, available at http://www. iranicaonline.org/articles/tahmasp-i (accessed on October 2015), 2009. Tinto, Alberto. La Tipografia Medicea Orientale, Lucca, Maria Pacini Fazzi, 1987.

Tyulayev, Semen Ivanovic. Miniatures of Babur Namah, Moscow, State Fine Arts Publishing House, 1960. 